\title{
Determination of Work Index for Iperindo Lode Gold Deposit at Ilesha Goldfield Osun State, Nigeria Using Modified Bond Index
}

\author{
Adetula Yomi Vincent", Ozah Blessing, Alabi Oladuni Oyelola, John Ade Ajayi, Akoja Ayo \\ Department of Metallurgical and Materials Engineering, Federal University of Technology, Akure, Nigeria \\ Email address: \\ Adetula.yomi1987@yahoo.com (A. Y. Vincent) \\ ${ }^{*}$ Corresponding author \\ To cite this article: \\ Adetula Yomi Vincent, Ozah Blessing, Alabi Oladuni Oyelola, John Ade Ajayi, Akoja Ayo. Determination of Work Index for Iperindo Lode \\ Gold Deposit at Ilesha Goldfield Osun State, Nigeria Using Modified Bond Index. American Journal of Materials Synthesis and Processing. \\ Vol. 4, No. 1, 2019, pp. 37-42. doi: 10.11648/j.ajmsp.20190401.15
}

Received: June 3, 2019; Accepted: July 3, 2019; Published: July 13, 2019

\begin{abstract}
Iperindo lode gold is one of the few primary gold deposits known in Nigeria. The mineralized lodes generally comprise highly silicified fine-grained foliated biotite gneiss typically intruded by both discordant and concordant pegmatitic quartz-feldspar veins. The research investigates the work index of Iperindo lode deposit at Ilesha goldfield in Osun state, Nigeria. The sample of the gold ore was sourced from Iperindo at Ilesha Local Government Area of Osun state, Nigeria. The reference ores (quartz) sample was also sourced from that serves as overburden to the goldmine. The test ore and the reference ore were characterized using Energy Dispersed X-ray fluorescence spectrometer. 500 grams of gold ore and quartz were sampled and prepared by crushing and grinding to $100 \%$ passing $710 \mu \mathrm{m}$ sieve; 100 grams of prepared ores were charged into array of sieve arranged in $\sqrt{ } 2$ i.e from $500 \mu \mathrm{m}$ to $-45 \mu \mathrm{m}$. Set of sieves were mounted on automated sieve shaker and was operated for 20 minutes. The work index of reference ore was used to calculate the work index of the test ore using Gaudin Schuman expression to obtain a work index of $11.92 \mathrm{kwh} /$ ton for test ore. This work index value obtained for Iperindo gold ore (test ore) lies favorably within the work index of $8-16.5 \mathrm{kwh} /$ ton for gold ore sighted in the literature.
\end{abstract}

Keyword: Iperindo Lode Ore, Work Index, Gold

\section{Introduction}

The solid minerals industry is one of the strongholds that contribute to any nation's gross domestic product [2]. The sector has great potentials in contributing greatly to the economy and it can stand as a source of job creation and by this, eradicate poverty [10]. Nigeria is one of the countries in the world blessed with abundant solid mineral deposits [3]. This constitute a wide range of mineral resources like galena, gold, sphalerite, columbite, tantalite, among others that provide bulk of raw materials for the industry [1]. Nigeria is highly mineralized, but backward technologically and industrially because value is hardly added to Nigeria's mineral resources. A country like Nigeria can overcome its present economic struggle if adequate attention is directed towards the solid mineral sector because it is pivotal to the economic and technological development of a nation [17].
Gold, a noble metal, is of economic, social and political significance. This precious metal is predominantly found in three regions in Nigeria: Ife-Ilesha goldfield, Binri-GwariMinna goldfield and Zamfara-Kebbi-Sokoto goldfield [1]. At least fifty gold occurrences have been reported from the three fields and two from outside the fields at Rimi in Kano State and Igbwa in Edo State. Ife-Ilesha gold stretches from Ilesha through Osu, Itagunmodi to the vicinity of Igun. Its gold occurs in two major forms: disseminated gold in quartz vein occurring in granite gneiss in Iperindo reef and alluvial gold associated with amphibolite in Igun reef [4]. Iperindo lode gold is one of the few primary gold deposits known in Nigeria. The mineralized lodes generally comprise highly silicified fine-grained foliated biotite gneiss typically intruded by both discordant and concordant pegmatitic quartz-feldspar veins. The veins are mainly as discrete particles, up to $100 \mu \mathrm{m}$ in size, at grain boundaries between 
quartz and carbonates and the most prominent and dominant sulphide in Iperindo lode gold deposit is pyrite [11]. Hence this research work on "Determination of Work index of Iperindo lode ore at Ilesha goldfield in Osun State, Nigeria" as panacea for the development of a process route for the beneficiation of the ore deposit to metallurgical grade.

Theoretical Consideration for Comminution Process (Work Index)

Work index is refer to the ease with which the mineral ore can be comminuted useful in designing of grinding system in mineral processing [16]. For a newly discovered ore it is very important to determine its hardness and grinding characteristics so that suitable power can be selected for its comminution. There are many theories of comminution, but paramount importance to this work is the modified Bond's equation called Berry and Bruce comparative Bond's equation that was used to determine the work index of the ore. Work index is the comminution parameter which expresses the resistance of material to crushing and grinding; it is the kilowatt hour per short-ton required to reduce the material from theoretically infinite feed size to $80 \%$ passing $100 \mu \mathrm{m}$ [18]. Table 1 gives the work index of some minerals ores sample.

Table 1. Gives the work index of some minerals ore samples.

\begin{tabular}{llll}
\hline Material & work Index & Material & Work Index \\
\hline Bauxite & $2.38-9.45$ & Limestone & $2.69-14.0$ \\
Copper & $12.7-14.0$ & Molybdenum & $11.6-14.10$ \\
Fluorspar & $2.98-9.76$ & quartz & $13.6-15.00$ \\
Graphite & $1.75-45.03$ & Titanium & $4.23-11.88$ \\
Gold & $8.0-16.5$ & Silica Sand & $2.65-16.46$ \\
\hline
\end{tabular}

Sources: $[13,5,14]$.

In the mineral industry, comminution is the highest consumer of energy [9]. It is imperative to know that size reduction is very expensive and the energy requirements as well as cost per tonne of ore comminuted increases from blasting $(0.43 \mathrm{kWh} / \mathrm{t})$ through crushing $(3.24 \mathrm{kWh} / \mathrm{t})$ to grinding $(10.0 \mathrm{kWh} / \mathrm{t})$ as the highest while efficiency decreases [6]. With the limited energy resources, the need to design energy requirements of engineering processes cannot be overemphasized. However, milling is the most expensive and yet the least efficient. In a comminution circuit, overall power consumption and power draw during milling are very important parameters [15]. Since milling is generally inefficient, it is necessary to maximize the use of energy that is available to the comminution circuit. A milling circuit is generally designed based on grindability and abrasive index tests carried out on samples during the plant design stages of the mines and the expected tonnage to be processed [8].

Using bond's law the work Index of an ore is determine by the comparing its grindability;

$$
\mathrm{W}_{\mathrm{r}}=\mathrm{W}_{\mathrm{t}}=\mathrm{W}_{\mathrm{ir}}\left[\frac{10}{\sqrt{p r}}-\frac{10}{\sqrt{F r}}\right]=\mathrm{W}_{\mathrm{it}}\left[\frac{10}{\sqrt{p t}}-\frac{10}{\sqrt{F t}}\right]
$$

hence,

$$
\mathrm{W}_{\mathrm{it}}=\mathrm{W}_{\mathrm{ir}}\left[\frac{10}{\sqrt{p r}}-\frac{10}{\sqrt{F r}}\right] \div \mathrm{W}_{\mathrm{it}}\left[\frac{10}{\sqrt{p t}}-\frac{10}{\sqrt{F t}}\right]
$$

Where

$\mathrm{W}_{\mathrm{r}}=$ Work Input of the reference ore; $\mathrm{W}_{\mathrm{t}}=$ Work input of the test ore; $\mathrm{W}_{\mathrm{ir}}=$ work index of reference;

$\mathrm{W}_{\text {ir }}=$ work index of test ore; $\mathrm{P}_{\mathrm{r}}=80 \%$ product (reference ore) passes, $\mathrm{P}_{\mathrm{t}}=80 \%$ product (test ore) passes

$F_{r}=80 \%$ feed (reference ore) passes; $F_{t}=80 \%$ feed (test ore) passes.

\section{Materials and Method}

\subsection{Materials}

$50 \mathrm{~kg}$ sample of Iperindo lode gold ore of which $20 \mathrm{~kg}$ of the sample used in this research work was obtained from Ilesha goldfield deposit site which is about 23 square kilometres. It lies within latitude $7^{\circ} 3^{\prime}$ and $7^{\circ} 35^{\prime}$ and longitude $4^{\circ} 30^{\prime}$. The quartz samples used as reference ore was sourced from Ilesha goldfield overburden, in osun state. Random sampling sampling method was used for true fraction representative of the ore, follow by Cone and quartering.

\subsection{Method}

The sample of the reference ore was broken manually with a sledge hammer to provide required size acceptable as feed to the Denver laboratory jaw crusher. The sample was crushed and ground. $100 \mathrm{~g}$ samples was weighed for sieve analysis. The modified Bond's method of determining the work index of ore involves use of reference ore of which grindability is known. The procedure is as follows;

1. $100 \mathrm{~g}$ each of samples of the ore under test and the reference ore were crushed and pulverized in the laboratory mill machine for an hour.

2. The samples of test and reference ores were taken and sized by sieving into a number of size fractions using the automatic sieve shaker for 20 minutes.

3. Each size fractions of the test and the reference ores were weighed and the value noted as "feed".

4. The "feed" test and reference ores were each gathered together and introduced into the Laboratory ball milling machine and ground for 1 hour.

5. The test and the reference ores from the laboratory ball mill machine were sized and each sieve fraction was weighed and the value noted as the product or discharge [12].

6. Sieveanalysis: $+500 \mu \mathrm{m},-500 \mu \mathrm{m}+355 \mu \mathrm{m},-355+250 \mu \mathrm{m},-$ $250+180 \mu \mathrm{m},-180+125 \mu \mathrm{m}, \quad-125+90 \mu \mathrm{m},-90+63 \mu \mathrm{m}, \quad-$ $63+45 \mu \mathrm{m}$ and $-45 \mu \mathrm{m}$

\section{Results and Discussion}

\section{Results}

(A) Test ore (Iperindo lode gold) and Reference (Overburden Quartz) as feed to the ball mill.

Table 2 gives the sieve analysis result of the feed to ball 
mill of the test ore (gold ore) and Figure 1 is the graph retained and cumulative passing of test ore. plotted showing sieve sizes against cumulative percentage

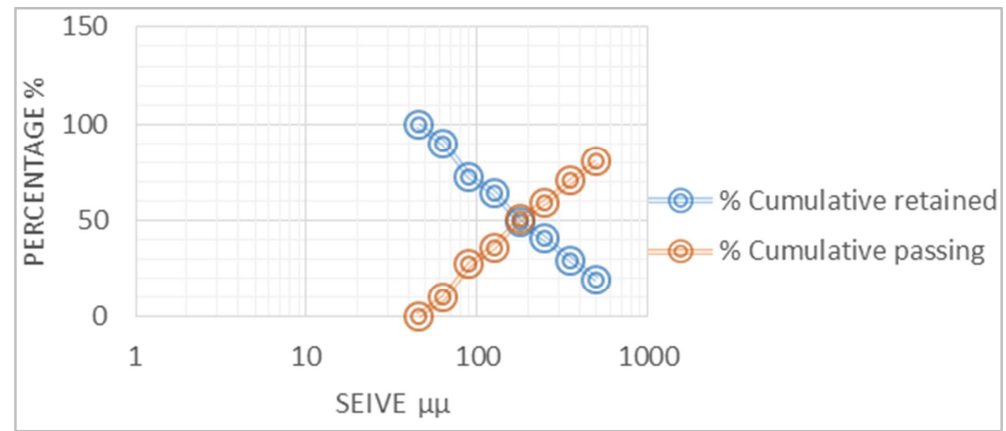

Figure 1. Shows sieve size (mm) against cumulative \% retained and cumulative \% passing of the Iperindo lode gold feed to the ball mill.

Table 2. Sieve analysis of crude sample of Iperindo gold ore (test ore) feed to the ball mill.

\begin{tabular}{lllll}
\hline Size range $(\boldsymbol{\mu m})$ & Weight retained $(\mathbf{g})$ & Weight retained $(\%)$ & \% Cumulative retained & \% Cumulative passing \\
\hline+500 & 19.23 & 19.56 & 19.56 & 80.44 \\
$-500+355$ & 9.77 & 9.94 & 29.50 & 70.50 \\
$-355+250$ & 11.1311 .32 & 40.82 & 59.18 & 51.01 \\
$-250+180$ & 8.03 & 8.17 & 48.82 & 35.90 \\
$-180+125$ & 14.87 & 15.11 & 64.10 & 27.43 \\
$-125+90$ & 8.33 & 8.47 & 72.57 & 10.17 \\
$-90+63$ & 16.97 & 17.26 & 89.83 & 0.64 \\
$-63+45$ & 9.37 & 9.53 & 99.36 & 0.00 \\
-45 & 0.63 & 0.64 & 100 & \\
\hline
\end{tabular}

Calculation using the value in Table 2 .

If $500 \mu \mathrm{m}=80.44$, Then $\mathrm{X}=80 \%$

Using Gaudin Schumann Expression:

$$
\begin{gathered}
\mathrm{P}(\mathrm{X})=100[\mathrm{X} / \mathrm{K}]]=100[\mathrm{X} / \mathrm{K}] \\
\alpha=\frac{\log \mathrm{P}\left(\mathrm{X}_{2}\right)-\log \mathrm{P}\left(\mathrm{X}_{1}\right)}{\log \left(\mathrm{X}_{2}\right)-\log \left(\mathrm{X}_{1}\right)} \\
\text { Size } 2=\frac{\left.(\text { Percentage passing size })_{2}\right)^{2} \text { Size }}{\left(\text { Percentage passing } \text { Size }_{1}\right)^{2}}
\end{gathered}
$$

$$
\mathrm{X} \mu \mathrm{m}=\frac{\left[\frac{80}{100}\right]^{2} \times 500}{\left[\frac{80.44}{100}\right]^{2}}=494.54 \mu \mathrm{m} \text { at } 80 \%
$$

Table 3 gives the sieve analysis result of the feed of reference (quartz) to the ball mill and Figure 2 is the graph plotted showing sieve sizes against cumulative percentage retained and cumulative passing of test ore.

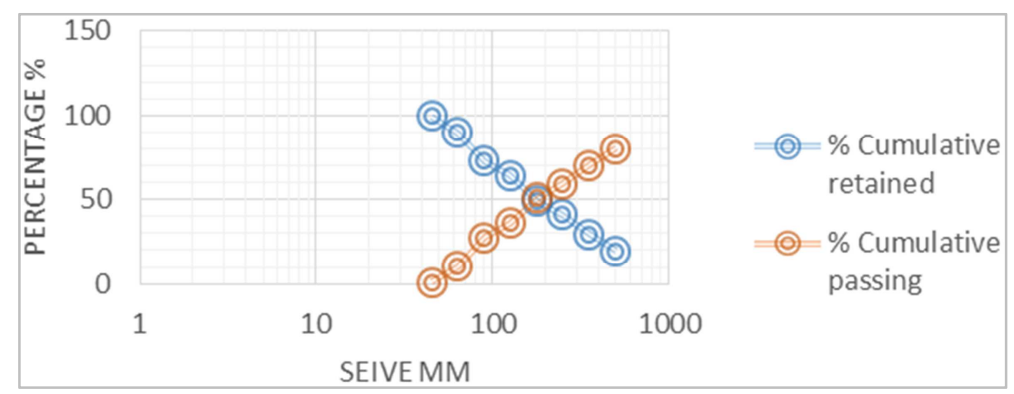

Figure 2. Is the plot of sieve size (mm) against \% cumulative retained and \% cumulative passing.

Table 3. Sieve analysis of overburden quartz sample (reference ore) feed to ball mill.

\begin{tabular}{lllll}
\hline Size range $(\boldsymbol{\mu m})$ & Weight retained $(\mathbf{g})$ & Weight retained $(\%)$ & \% Cumulative retained & \% Cumulative passing \\
\hline+500 & 20.23 & 20.43 & 20.43 & 79.57 \\
$-500+355$ & 11.20 & 11.31 & 31.74 & 68.26 \\
$-355+250$ & 11.47 & 11.59 & 43.33 & 56.67 \\
$-250+180$ & 9.47 & 9.57 & 52.90 & 47.10 \\
$-180+125$ & 13.87 & 14.01 & 64.91 & 35.09 \\
$-125+90$ & 7.37 & 7.44 & 74.35 & 25.65 \\
$-90+63$ & 10.30 & 10.40 & 84.75 & 15.25 \\
$-63+45$ & 12.27 & 12.39 & 97.14 & 2.86 \\
-45 & 2.83 & 2.86 & 100 & 0.0 \\
\hline
\end{tabular}


Calculation using the value in Table 3.

If $500 \mu \mathrm{m}=79.57$

Then $\mathrm{X}=80 \%$

$$
X \mu \mathrm{m}=\frac{\left[\frac{80}{100}\right]^{2} \times 500}{\left[\frac{79.57}{100}\right]^{2}}=505.42 \mu \mathrm{m} \text { at } 80 \%
$$

Test ore (Iperindo lode gold)/Reference Quartz) as product discharge from the ball mill

Table 4 gives the sieve analysis result of the product to ball mill of the test ore (gold ore) and Figure 3 is the plot of the sieve sizes against $\%$ cumulative retained and $\%$ cumulative passing of test ore.

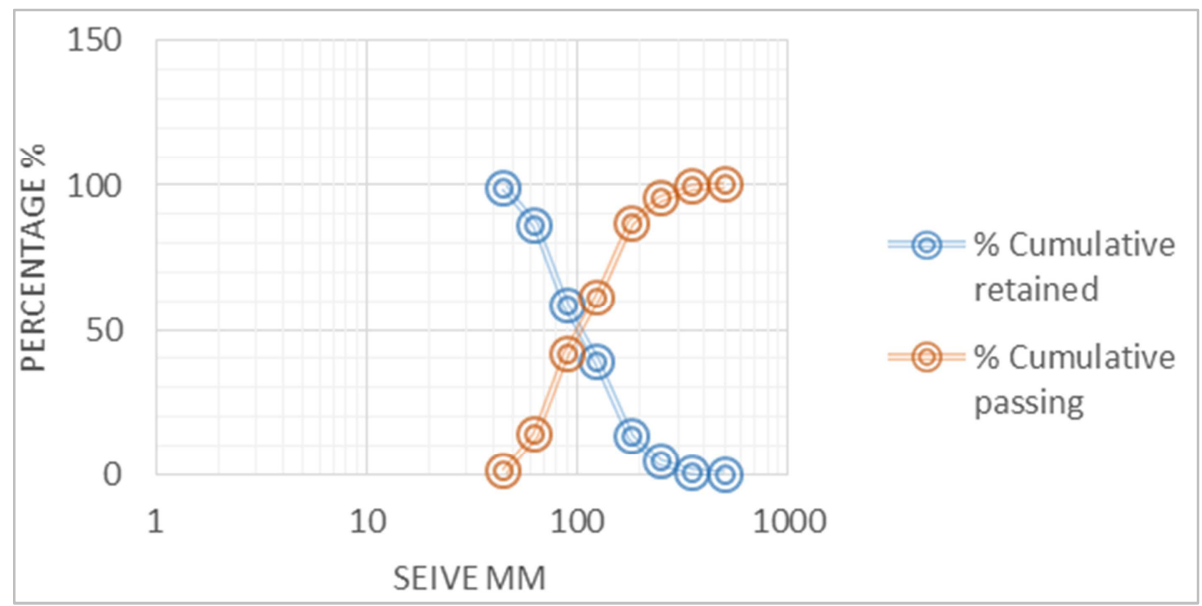

Figure 3. Shows sieve size $(\mu \mathrm{m})$ against cumulative $\%$ retained and cumulative \% passing.

Table 4. Sieve analysis of Iperindo gold ore (test ore) product from the ball mill.

\begin{tabular}{lllll}
\hline Size range $(\boldsymbol{\mu} \mathbf{m})$ & Weight retained $(\mathbf{g})$ & Weight retained $(\%)$ & \% Cumulative retained & \% Cumulative passing \\
\hline+500 & 0.00 & 0.00 & 0.00 & 100 \\
$-500+355$ & 0.43 & 0.44 & 0.44 & 99.56 \\
$-355+250$ & 3.93 & 3.98 & 4.42 & 95.58 \\
$-250+180$ & 8.60 & 8.72 & 13.14 & 86.86 \\
$-180+125$ & 25.27 & 25.62 & 38.76 & 41.67 \\
$-125+90$ & 19.30 & 19.57 & 58.33 & 13.76 \\
$-90+63$ & 27.53 & 27.91 & 86.24 & 0.91 \\
$-63+45$ & 12.67 & 12.85 & 99.09 & 0.00 \\
-45 & 0.90 & 0.91 & 100 & \\
\hline
\end{tabular}

Calculation using the value in Table 4.

If $180 \mu \mathrm{m}=86.86$

Then $\mathrm{X}=80 \%$

$$
\mathrm{X} \mu \mathrm{m}=\frac{\left[\frac{80}{100}\right]^{2} \times 180}{\left[\frac{86.86}{100}\right]^{2}}=152.69 \mu \mathrm{m} \text { at } 80 \%
$$

Table 5 gives the sieve analysis result of the product to ball mill of the test ore (gold ore) and Figure 4 is the plot of the sieve sizes against \% cumulative retained and \% cumulative passing of test ore.

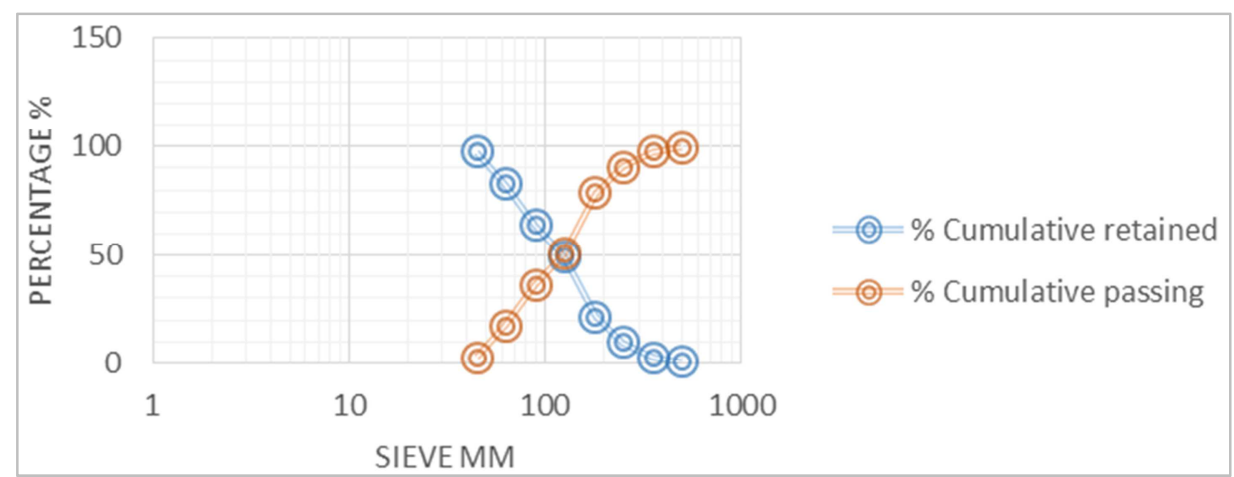

Figure 4. Shows sieve size ( $\mu m$ ) against cumulative \% retained and cumulative \% passing of the Iperindo lode gold product from the ball mill. 
Table 5. Sieve analysis of overburden quartz sample (reference ore) product from the ball mill.

\begin{tabular}{lllll}
\hline Size range $(\boldsymbol{\mu m})$ & Weight retained $(\mathbf{g})$ & Weight retained $(\%)$ & \% Cumulative retained & \% Cumulative passing \\
\hline+500 & 0.40 & 0.44 & 0.44 & 99.60 \\
$-500+355$ & 2.13 & 2.15 & 2.55 & 97.45 \\
$-355+250$ & 7.00 & 7.07 & 9.62 & 90.38 \\
$-250+180$ & 11.83 & 11.96 & 21.58 & 78.42 \\
$-180+125$ & 27.33 & 27.63 & 49.21 & 50.79 \\
$-125+90$ & 14.47 & 14.63 & 63.84 & 36.16 \\
$-90+63$ & 18.67 & 18.87 & 82.71 & 17.29 \\
$-63+45$ & 14.60 & 2.66 & 100 & 2.63 \\
-45 & 2.60 & 2.63 & & 0.00 \\
\hline
\end{tabular}

Calculation using the value in Table 5.

If $180 \mu \mathrm{m}=78.42$

Then $\mathrm{X}=80 \%$

$$
X \mu \mathrm{m}=\frac{\left[\frac{80}{100}\right]^{2} \times 180}{\left[\frac{78.42}{100}\right]^{2}}=187.33 \mu \mathrm{m} \text { at } 80 \%
$$

Using Bond's Equation Equation (2)

$$
\mathrm{W}_{\mathrm{it}}=\mathrm{W}_{\mathrm{ir}}\left[\frac{10}{\sqrt{P r}}-\frac{10}{\sqrt{F r}}\right] \div\left[\frac{10}{\sqrt{p t}}-\frac{10}{\sqrt{F t}}\right]
$$

Using overburden quartz as a reference ore and Iperindo lode gold as the test ore

$\operatorname{Pr}=187.33 \mu \mathrm{m}, \mathrm{Fr}=505.42 \mu \mathrm{m}, \mathrm{Pt}=152.69 \mu \mathrm{m}, \mathrm{Ft}=$ $494.54 \mu \mathrm{m}$, Wir $=15$ (work index of quartz [5])

Therefore:

$$
\begin{gathered}
\mathrm{W}_{\text {it }}=15\left[\frac{10}{\sqrt{187.33}}-\frac{10}{\sqrt{505.42}}\right] \div\left[\frac{10}{\sqrt{152.69}}-\frac{10}{\sqrt{494.54}}\right] \\
=11.92 \mathrm{kwh} / \mathrm{ton}
\end{gathered}
$$

\section{Discussion}

The results and the plots of the particle size analysis of the reference (quartz) and test ore (Iperindo lode ore) for both the feeds and products sieves size are shown in Table 2-5 and Figure 1-4. The $80 \%$ passing sieve fraction for both feed and product of the crude Iperindo lode gold ore sample was found to be $494.54 \mu \mathrm{m}$ and $152.69 \mu \mathrm{m}$ respectively. While the work index for the crude Iperindo gold ore sample was computed to be $11.92 \mathrm{kWh} /$ ton on the average which when compared to the work index of other gold ores, the result obtained lies favorably with the work indexes of $8-16.5 \mathrm{kWh} /$ ton for gold ores sighted in the literatures. The $11.92 \mathrm{kwh} /$ ton work index obtained for Iperindo lode gold ore sample means that about $11.92 \mathrm{kwh}$ of energy is required to reduce one ton of Iperindo lode gold ore sample from $80 \%$ passing of $494.54 \mu \mathrm{m}$ to $80 \%$ of $152.69 \mu \mathrm{m}$. Furthermore, the value of the work index obtained for the Iperindo lode gold ore may be said to be valid only over the size range of particle considered. It is noteworthy, breaking characteristic of most ores varies with particle size and this brings about variation in the work index with particle size [16].

\section{Conclusion}

In conclusion the work Index of Iperindo lode gold ore from llesha goldfield in osun state, Nigeria has been determined and found to be $11.92 \mathrm{kwh} /$ ton on average. This parameter serves as panacea for the development of a process route for the beneficiation of Iperindo lode gold ore deposit to metallurgical grade. Nigeria which is highly mineralized, but backward technologically and industrially can benefit immensely via the exploration, exploitation, processing, extraction and utilization of the depletable resources as a result of this, overcome its present economic struggle if adequate attention is directed towards the solid mineral sector because it is pivotal to the economic and technological development of a nation.

\section{References}

[1] Ajayi, J. A. (2004): "An Assessment of the Amenability of Ilesa Gold Ore to Amalgamation and Percolation Leaching", Journal of Mining and Geology, 37 (1), Pp. 85-90.

[2] Alabi Oladunni Oyelola; dalhatu Aboki Abdu, Abere Dare Victor; igonwelundu Magnus T; bala Meshack Bosan; araoye Babatunde Oyebode J. (2016) Extraction of a Low Grade Zinc Ore using Gravity and Froth Flotation Methods Appl. Sci. Environ. Manage. Vol. 20 (4) 903-908.

[3] Alabi Oladunni Oyelola, Shehu A. Y, George T. D, Ferdinand A., Emmanuel T. D (2015) Determination Of Work Index Of Gyel-Bukuru Columbite Ore In Plateau State, Nigeria.

[4] De Swardt A. M. J. (1947) Ife-Ilesa Gold-Field (Interim Report No 2): Geological Survey of Nigeria Annual Report, pp 14-19.

[5] Doering International GMBH (www.cylpibs.com).

[6] Higgins, M. (1998), "Jksimblast - Blast Simulation And Management”, Presented At Blasting Analysis International Eighth HighTech Seminar, Nashville, Tennessee, Pp. 1-9.

[7] Kanchibotla, S. S. (2000), "Mine To Mill Blasting To Maximise The Profitability Of Mineral Industry Operations", Proc. 27th ISEE Conf., Anaheim, USA.

[8] Levin, J. (1992), "Indicators Of Grindability And Grinding Efficiency”, J. S. Afr. Inst. Min. Metall., Vol. 92, No. 10, Pp. 283-289. 
[9] Napier-Munn, T. J. Morell, S., Morrison, R. D. \& Kojovic, T (1996). "Mineral comminution Circuits. their Operation and Optimisation". JKMRC Monograph Series in Mining and Mineral Processing 2, University of Queensland, Australia, 1996.

[10] Olumide, S. A., Akongwale, S. and Udefuna, P. N. (2013): Economic Diversification in Nigeria: Any Role for Solid Mineral Development? Published by MCSER CEMAS Sapienza University of Rome. Vol: 4 No: 6 pg691.

[11] Oyinloye, A. O., Steed, G. M. (1996) Geology and geochemistry of Iperindo gold deposits, Ilesha schist belt, southwestern Nigeria. Trans. Instn. Min. Metall. (Set. B. Appl. Earth Sci.) 105: B71 -B81Olatunji K. J.

[12] Durojaiye A. G., (2010); Determination Of Bond Index Of Birnin - Gwari Iron Ore In Nigeria, Journal Of Minerals And Materials Characterization And Engineering, Vol. 9, No. 7, Pp. 637-642, Jmmce. Org, USA. Thomas.

[13] D. G., Asuke, F. And Yaro, S. A. (2014) Determination Of Some Conceptual Mineral Processing Parameters Of SobaWanka Pyrochlore-Col Tan Mineral Ore Deposit. 2014
Nigeria Engineering Conference, 15-18 August 2014, 2, 3241.

[14] Table of material reported by fred bond www.911metallurgist.com.

[15] Siddall, B., Henderson, G., And Putland, B. (1996), "Factors Influencing Sizing Of SAG Mills From Drill Core Samples", Proc. Conf. International AG And SAG Grinding Technology, UBC, Vancouver, Canada, Vol. 2, Pp. 463.

[16] Yaro S. A., (1996); Grindability Test For Ririwai Lead-Zinc Complex Ore; Journal Of Nigeria Mining.

[17] Bamidele, E. A., Adetula Y. V., Yakubu N. A (2013) Timely Completion of Nigeria IronAnd Steel Projects: The imperative Of Technical Manpower Development Paper Presented At The 29th Annual Conference And AGM Of Nigerian Metallurgical Society At Ajaokuta Steel Company, From Thursday 31st October, 2013 To 2nd November.

[18] Wills, B. A. and Napier-Mum, T. J. (2006) Mineral Processing Technology. 7th Edition, Elsevier Science \& Technology Books, Amsterdam, 109-439. 